https://doi.org/10.22364/htqe.2021.69

\title{
OUTPUTS OF A PHD COURSE ON THE EUROPEAN POLICY OF FOREIGN LANGUAGE TEACHER EDUCATION
}

\author{
Ismail Hakki Mirici \\ Hacettepe University, Turkey
}

\begin{abstract}
The European Commission has developed several standard documents for foreign language education including teacher education and opened access for the common use of all European counterparts. This study is based on a PhD course aiming at increasing awareness of and fostering deep research about foreign language teacher education policy in Europe. The study aimed to scrutinize the opinions of the PhD students in the field of English Language Teaching (ELT) about the European foreign language teacher education policy. In the study, the case study research design was adopted, utilizing qualitative data. The participants of the study were selected via total count sampling model and covered all of the PhD students $(N=9)$ taking the course entitled "Foreign Language Teacher Education Policy in Europe" with the code: IDO710 within the ELT program of the Hacettepe University Graduate School of Educational Sciences in the Fall Semester of 2020-2021 academic year. The data were collected via students' self-reflection reports after the course had been completed and were analysed using content analysis as one of the qualitative data analysis methods. The results showed that at the end of the course the participant students' awareness was highly increased about the European foreign language teacher education policy and related documents; they decided to make use of these documents in their own contexts; they had a deeper understanding of the English as a Foreign Language (EFL) teacher education; and they became determined to carry out further research on the effectiveness of the European documents on EFL teacher education in Turkey.
\end{abstract}

Keywords: English Language Teaching, European documents, European policy, foreign language teachers, teacher education.

\section{Introduction}

Teacher education (TE) process comprises the procedures on developing prospective teachers in terms of knowledge, attitudes, behaviours and skills they need while performing their professional activities in the classroom, 
school and the related contexts. The TE process in Europe is divided into three career stages: (a) initial education, (b) induction period, (c) professional education as given below:

a. Initial education covers the college period during which they attend classes to develop their knowledge and skills on didactic, general knowledge as well as their field of teaching.

b. Apprenticeship/induction is the first year of exposure to professional activities and teaching in a particular educational institution.

c. Professional development refers to one-shot or continuous in-service teacher training activities designed for teachers to catch up with the latest educational developments (European Commission, 2011, 2013).

The process of TE is the subject of national educational policy in most countries, reflecting both values and cultures besides considering financial resources. The degree of political control over TE varies depending on the government, and in most developed systems it is the subject of detailed prescription of a governmental body. The government specifies the skills that all teachers must possess, or it specifies the content of TE courses in order to avoid confusions about standardization. For instance, the European Union policy of foreign language teacher education requires a broad description in which European language teachers are expected to fulfil the requirements in the Common European Principles for Teacher Competences and Qualifications (European Centre for the Development of Vocational Training [CEDEFOP], 2009). The related documents are the following:

- The Common European Framework of Reference for Languages CEFR (Council of Europe [CoE], 2001) is a descriptive \& educational document based on 3 principles (learner autonomy, self-assessment, cultural diversity), and an action oriented approach.

- The European Language Portfolio - ELP (Little, 2009) comprises 3 components (Language Biography, Language Passport, Dossier) as a self-assessment, recording and reporting tool.

- The European Portfolio for Student Teacher of Languages - EPOSTL (Newby, 2007) covers 3 main parts; Personal Statement, Self- assessment and dossier, and is composed of 193 descriptors in 7 categories namely: Context, Methodology, Resources, Lesson Planning, Conducting a Lesson, Independent Learning, and Assessment of Learning.

- The European Profile for Language Teacher Education - EPFLTE (Kelly \& Grenfell, 2004) is made up of 4 sections: Structure, Knowledge and Understanding, Strategies and Skills, and Values covering 4 items of description. 
- The European Profiling Grid for Language Teachers (European Commission, 2011) provides valuable input to the descriptors in the self-assessment for teachers in service and covers 4 key areas: Qualifications, teacher training, and experience; Core competences (methodology - knowledge \& skills, lesson and course planning, interaction with and monitoring of learners, assessment); Enabling skills (language awareness, intercultural competence and the ability to use digital media); and Professionalism.

Considering these, the following research question of the study was formulated: "What are opinions of PhD students in the field of English Language Teaching (ELT) at the Hacettepe University in Ankara, Turkey about the foreign language teacher education policy in Europe?"

\section{Method}

The study was based on a qualitative research design. Qualitative research involves collecting and analysing non-numerical data to understand concepts, opinions, or experiences. It can be used to gather in-depth insights into a problem or generate new ideas for research (Bryman, 2008). The details about the method of the study are as follows:

\section{Participants}

The participants of the study were selected via total count sampling model on voluntary basis. They were all of the PhD students $(N=9)$ taking the course entitled: "Foreign Language Teacher Education Policy in Europe" with the course code: IDO710 within the English Language Teaching (ELT) program in the Fall Semester of 2020-2021 academic year at the Hacettepe University Graduate School of Educational Sciences. In the first class hour of the course, the students were informed about the purpose and the method of the study, and they were invited to take part in it. All the students agreed to participate in the study voluntarily.

\section{Data collection and analysis}

The data were collected via students' self-reflection reports after the course had been completed. The self-reflection reports were blinded and analysed anonymously via content analysis as one of the qualitative data analysis methods.

\section{Procedure}

The study was based on the aforementioned course, which lasted for 16 weeks in the Fall Semester of 2020-2021 academic year. The details of the course are given below. 
Course Aims. Students understand the concept of foreign language teacher education in Europe. They develop skills for making use of various standard documents of European foreign language teacher education in different contexts, and they have the knowledge and confidence to conduct research for further studies on this subject.

\section{Learning Outcomes:}

- Understanding the core concept of foreign language teacher education, its procedure and the practices in Europe;

- Understanding how to adapt European teacher education systems in their own context;

- Identifying their own foreign language teacher education policy comparing and contrasting with other countries in Europe;

- Developing the core European competencies necessary for teacher education;

- Applying scientific methods and techniques for developing a research on teacher education.

\section{Course Outline}

Table 1. Weekly Course Outline

\begin{tabular}{|l|l|}
\hline Weeks & Topics \\
\hline Week 1 & $\begin{array}{l}\text { Introduction to the course and to the Foreign Language Teacher } \\
\text { Education in general }\end{array}$ \\
\hline Week 2 & $\begin{array}{l}\text { Association for Teacher Education in Europe - ATEE \& Handbook for } \\
\text { teacher training }\end{array}$ \\
\hline Week 3 & European Portfolio for Student Teachers of Languages (EPOSTL) \\
\hline Week 4 & Revision \\
\hline Week 5 & European Profile for Language Teachers Education \\
\hline Week 6 & Revision \\
\hline Week 7 & Supporting Teachers Educators \\
\hline Week 8 & $\begin{array}{l}\text { Supporting Teacher Competence Development for Better Learning } \\
\text { Outcomes }\end{array}$ \\
\hline Week 9 & Mid-term \\
\hline Week 10 & Discussion on relevant articles \\
\hline Week 11 & Continuous Professional Development (CPD) for Teachers in the UK \\
\hline Week 12 & $\begin{array}{l}\text { Innovations in pre-service education and training for English language } \\
\text { teachers }\end{array}$ \\
\hline Week 13 & Revision \\
\hline Week 14 & Discussions \\
\hline Week 15 & Presenting final report \\
\hline Week 16 & Final remarks and closing the class \\
\hline
\end{tabular}




\section{Results}

In the study, since the participating students were $\mathrm{PhD}$ students of ELT Department, and since they were proficient in English language with English language background, the medium of communication during the data collection period was English, and their responses were in English. There was no need for translation.

Findings of the study are presented and illustrated in Table 2 below.

Table 2. Participants' Reflections on Their Achievements in the Course Entitled "Foreign Language Teacher Education Policy in Europe"

\section{Themes. Statements}

\section{Theory and Practice}

As an integral part of the educational system, teacher education is closely related to the society.

Educating high-quality teachers is one of the most important problems which should be solved by policy makers.

Teacher education is a lifelong process which starts with pre-service/initial teacher education, leads to early career support and goes on with continuous professional development (CPD).

Teacher-autonomy and cultural diversity are the points that are emphasized in European teacher education policies.

Teachers play crucial roles in the development of any nation.

\section{Internationalization}

Becoming a member of Association for Teacher Education in Europe (ATEE) and European Association for Language Testing and Assessment (EALTA) was one of the most important achievements of this course.

I believe that collaboration with colleagues is as important as intellectual development in teacher education.

Teachers in professional development setting in which they develop their teaching skills as a part of continuous development can also be members of some organizations. One of them is called EALTA.

People who are interested in language testing can keep in touch with other teachers from different countries by considering cultural autonomy.

Being an English language teacher requires to become a member of a worldwide community.

\section{Documentations}

All the documents were connected to each other just like the pieces of a chain. This connection ensured that the foreign language teacher education system made sense.

Another precious document that we discussed was the European Portfolio for Student Teachers of Languages (EPOSTL).

The European Profiling Grid gives us a new point of view. It categorizes professional development phases into three. 
The Supporting Teacher Educators has suggestions for policy makers. The examples from different countries which are presented in this document shows the current policies on teacher educators, which provides us with an opportunity to make comparisons among them.

The European Portfolio for Student Teachers of Languages (EPOSTL) can scaffold reflective teacher learning in language teacher education.

Throughout the course, we were informed about EPOSTL, European Profile for Language Teacher Education, Supporting Teachers Educators, CPD, Supporting Teacher Educators and Supporting Teacher Competence Development. What these documents have in common is that they are not prescriptive, they present guiding principles.

The European Portfolio for Student Teachers of Languages (EPOSTL), which is a document for pre-service teachers to encourage them to reflect on their skills and knowledge, assess their own didactic competences, monitor their progress and record their experiences of teaching during the course of their teacher education, has a direct contribution to teacher autonomy.

The European Profile for Language Teacher Education is a document about which I have not been informed before. It presents a toolkit of 40 items which could be included in a teacher education program to equip language teachers with the necessary skills and knowledge.

The Supporting Teacher Educators is of great importance in the field of teacher training. The document gives information about who the teacher educators are and what skills and competences they need to develop.

I believe that introducing and using EPOSTL during teaching practicum experience can be very fruitful for student-teachers. Student teachers can be autonomous in their future lives.

The European Profiling Grid is designed to help teachers see and track their qualifications and competencies by assisting them through the requirements in four different areas.

Teachers in professional development setting can study the European Profile for Language Teacher Education, the Supporting Teacher Competence Development, and the Supporting Teacher Educators, which all have descriptive nature rather than prescriptive.

Given the teacher orchestrating what happens in the classroom, the importance of the European Profiling Grid (EPG) is unquestionable. It is an innovative tool describing the competences of language teachers.

\section{Awareness of Local System}

Taking a critical eye towards the current teacher education policy in Turkey and stepping out of the boundaries through learning about the implementations in Europe are necessary. In this regard, I believe that this course has addressed this need and enabled me to broaden my perspective in teacher education.

Teacher education is a critical component of education systems. I believe that this course provided me with in-depth insight with regard to the regulations and policies in teacher education across Europe. Having completed the course, I can say that teacher education in Turkey has neglected points when compared to the European policies. Therefore, as a PhD candidate and a teacher, I believe that more attention is needed to the field of teacher education. 
Throughout the course, I had a chance to self-reflect. As a language teacher, I had some questions about who I am, what didactic knowledge, competences, and skills I have had, what qualifications the teacher training program from which I graduated offered me, where I am in my professional journey, what I can do for my personal and professional growth.

\section{Fostering Further Researches}

This course offers me a new perspective in terms of foreign language teacher education. The documents we analysed and the discussions we made were really useful to understand the core concepts of teacher education. This course was a rewarding experience for me to learn the principles of teacher education, and I would like to conduct different researches by taking these principles into consideration.

With the help of this course, my research scope has changed so much, and I will make changes regarding foreign language teaching process in the institution I work.

What I have learned so far in teacher education policies allows me to notice spaces to be opened for the scope of further research agendas, fostering an interest in the development of teacher education programs.

\section{Self-achievements}

Throughout the semester, we analysed different handbooks which focused on different aspects of teacher education.

With the help of this lesson and the readings, I have realized that teacher education is a cumulative process that never ends. Besides, I could also generate my own ideas related to teacher education to support teachers in different settings.

Seeing that teacher educators are also given value is great and fruitful because even if we are teachers now, we can be teacher educators in the future. Hence, teachers should also prepare themselves to be mentors in the future as a part of their continuous development.

In teacher education programs, grey areas important to recognize or areas which are often ill-defined compel me to question taken-for-granted assumptions of teacher development. I have reshaped my thoughts to establish a revitalized perspective that avoids one size fits all models in the spirit of reflexivity and professional development.

We were able to lay out the aspects of teacher education landscape, gain a wellrounded understanding and insights of these complicated issues under the scope the European-based frameworks.

A Europe-wide set of standards for language teacher training are at the heart of offering such an opportunity with all angles covered. Getting acquainted with policy examples of the European countries enriches my holistic understanding of teacher/teaching competences and how to help teachers to acquire and develop professional competences throughout their careers.

Thanks to the course, I feel developed academically and professionally.

I have learnt about the international associations for teacher education such as ATEE and EALTA.

One of the biggest achievements of this course for me was the chance to examine the EPOSTL in detail. In addition, I have learnt about the European Profiling Grid (EPG). 


\section{Discussion}

The results revealed that the participant students had an opportunity to understand the fundamentals of foreign language teacher education policy in Europe. They were also able to compare and contrast their education policy with other countries in Europe. Referring to the European Commission's (2013) document, they emphasized their need for developing a policy for a comprehensive and qualified education of teacher trainers in Turkey. Taking steps in this direction, the participants reflected their benefit from the European Commission's documents that introduce a menu of choices and hold descriptive and educational items in a flexible, adaptable, and user-friendly way. For instance, the Common European Framework of Reference for Languages (CoE, 2001) presents valid descriptions of language levels and skills in a comprehensive and user-friendly way. Likewise, a coherent and system-wide induction programs for beginning teachers could be developed using an additional European document (European Commission, 2010). All the documents were built upon the common European principles and values, and they were helpful for the participant students to understand Europe's teacher training concept as contemporary practices in Europe (Mirici, 2015). Among the documents, there was one called "Supporting Teacher Educators for Better Learning Outcomes" which presented an understanding of how to support teacher educators (European Commission, 2013). A booklet prepared by the British Council (2013) was also helpful to make the participant students realize different aspects of teacher education.

The Companion Volume of the CEFR (CoE, 2020) was not included in the study because it was the main content of another elective course in the Spring Semester. All in all, it might be safe to claim that the participants definitely felt accomplished and developed about the documents and the teacher education policies in Europe, also referring to the democratic citizenship competencies (Salema, 2005).

\section{Conclusions and Recommendations}

As prospective academics, the participants gained a deep insight on teacher development policies in foreign language teaching and found an opportunity to broaden their outlook on teacher training implementations in relation with the underlying principles by completing course introduced in this study. They all got familiar with the practical knowledge on how to support novice language teachers, the components of each document, and the specific functions European-wide. They learnt the documents that are consistent with each other and the system is coherent among learning, 
teaching and teacher training in general. In conclusion, the course helped them to infer that the European policy in foreign language teacher education helps language learners, teachers (pre- and in-service), teacher educators, policymakers and associations understand that success emerges from the unity. It is also an important achievement of the participants that they intended to conduct further researches on the subject.

The results of the study were based on the reflections of only nine $\mathrm{PhD}$ students at Hacettepe University in Ankara, Turkey, and all the European documents were not included in the study. It may be recommended that to get a larger picture of the situation, some other larger scale projects or researches be conducted covering more countries, diverse institutions, more student population, and all related documents.

\section{References}

British Council. (2013). Innovations in Pre-service Education and Training for English Language Teachers. Retrieved from: https://www.teachingenglish.org.uk/sites/teacheng/ files/C442_Innovations_PRESETT_FINAL_WEB\%20ONLY_v2.pdf

Bryman, A. (2008). Social Research Methods. Oxford: Oxford University Press.

Council of Europe. (2001). Common European Framework of Reference for Languages. Cambridge: CUP.

Council of Europe. (2020). European Language Portfolio. Retrieved from: https://www. coe.int/en/web/portfolio/introduction

Council of Europe. (2020), Common European Framework of Reference for Languages: Learning, teaching, assessment - Companion Volume, Council of Europe Publishing, Strasbourg. Retrieved from: www.coe.int/lang-cefr.

European Centre for the Development of Vocational Training. (2009). Common European Principles for Teacher Competences and Qualifications. Retrieved from: https://www. cedefop.europa.eu/en/news-and-press/news/common-european-principles-teachercompetences-and-qualifications

European Commission. (2010). Developing coherent and system-wide induction programs for beginning teachers: a handbook for policymakers. Retrieved from: http://ec.europa.eu/ assets/eac/education/policy/school/doc/handbook0410_en.pdf

European Commission. (2011). European Profiling Grid. Retrieved from: https://www. eaquals.org/resources/european-profiling-grid-booklet

European Commission. (2013). Supporting Teacher Educators for Better Learning Outcomes. Retrieved from: https://ec.europa.eu/assets/eac/education/policy/school/doc/supportteacher-educators_en.pdf

Kelly, M., \& Grenfell, M. (2004). European Profile for Language Teacher Education A Frame of Reference. Southampton: University of Southampton. Retrieved from: http://www. lang.soton.ac.uk/profile/report/MainReport.pdf

Little, D. (2009). The European Language Portfolio: where pedagogy and assessment meet. Graz: ECML. 
Mirici, I. H. (2015). Contemporary ELT Practices Across Europe. International Journal of Language Academy - IJLA. 3(4), 1-8.

Newby, D. (2007). European Portfolio for Student Teachers of Languages A reflection tool for language teacher education. Strasbourg: Council of Europe. Retrieved from: http:// archive.ecml.at/mtp2/fte/pdf/c3_epostl_e.pdf

Salema, M. H. (2005). Teacher and Trainer Training in Education for Democratic Citizenship Competencies, Methods, and Processes. Retrieved from: http://www.jsse.org/index.php/ jsse/article/viewFile/994/897 